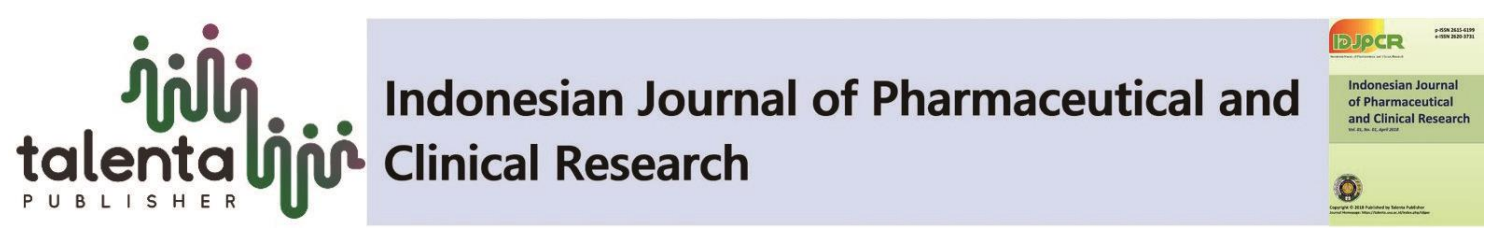

\title{
Analysis of Amoxicillin and Tetracycline Residues in Chicken Meat Using High Performance Liquid Chromatography-Mass Spectrometry
}

\author{
Mustika Furi* 1, Morin, Siti Sinaga ${ }^{2}$, Putra, Effendy De Lux ${ }^{2}$ \\ ${ }^{1}$ Department of Chemistry Pharmacy, Sekolah Tinggi Ilmu Farmasi Riau, Pekanbaru-Riau \\ ${ }^{2}$ Department of Chemistry Pharmacy, Faculty of Pharmacy, Universitas Sumatera Utara, Medan 20155, \\ Indonesia
}

\begin{abstract}
Antibiotics are commonly used as food additives in broiler farms and their use tends to be excessive regardless and incorrect that can leave some antibiotic residues in chicken meat. The aim of this study was to analyze on antibiotic residues level amoxicillin and tetracycline in chicken meat sold in five market in Medan. The antibiotic residues analysis was conducted by extracting the antibiotics from chicken meat with water and acetonitrile $(2: 8, \mathrm{v} / \mathrm{v})$ and detected by high performance liquid chromatography-mass spectrometry detector using C-18 column $(4.6 \mathrm{~mm}$ i.d., length $30 \mathrm{~mm}$, particle size $1.8 \mu \mathrm{m})$ at $35{ }^{\circ} \mathrm{C}$, with the mobile phases $0.1 \%$ formic acid solution in water and $0.1 \%$ formic acid solution in methanol with gradient elution technique at a flow rate of $0.5 \mathrm{ml} /$ minute. The result exhibited that the chicken meat that were collected from the five markets in Medan apparently contained tetracycline residues. The level of tetracyclin residue in chicken meat was $0.1157-1.4436 \mu \mathrm{g} / \mathrm{g}$, which exceed the maximum level of tetracyclin residue allowed in foodstuffs of animal origin which is $0.1 \mu \mathrm{g} / \mathrm{g}$.
\end{abstract}

Keywords: residue, antibiotic, amoxicillin, tetracycline, chicken meat

\begin{abstract}
Abstrak. Antibiotik biasanya digunakan sebagai bahan tambahan pada makanan di peternakan broiler dan terlepas dari penggunaannya cenderung berlebihan dan tidak benar yang dapat meninggalkan residu antibiotik dalam daging ayam. Tujuan dari penelitian ini adalah untuk menganalisis kadar residu antibiotik amoksisilin dan tetrasiklin pada daging ayam yang dijual di Medan. Analisis residu antibiotik dilakukan dengan mengekstraksi antibiotik dari daging ayam dengan air dan asetonitril $(2: 8, v / v)$ dan dideteksi dengan kromatografi cair kinerja tinggi - detektor spektrometri massa menggunakan kolom C-18 (id 4,6 mm, panjang $30 \mathrm{~mm}$ ), ukuran partikel 1,8 $\mu \mathrm{m}$ ) pada 35 ${ }^{\circ} \mathrm{C}$, dengan fase gerak, larutan asam format 0,1\% dalam air dan larutan asam format 0,1\% dalam metanol dengan teknik elusi gradien pada laju aliran 0,5 $\mathrm{ml} /$ menit. Hasilnya menunjukkan bahwa daging ayam yang dikumpulkan dari lima pasar di Medan ternyata mengandung residu antibiotik tetrasiklin. Tingkat residu tetrasiklin dalam daging ayam adalah 0,1157-1,4436 $\mu \mathrm{g} / \mathrm{g}$, yang melebihi tingkat maksimum untuk residu tetrasiklin yang diperbolehkan dalam bahan makanan asal hewan yaitu 0,1 $\mu \mathrm{g} / \mathrm{g}$.
\end{abstract}

Kata kunci: residu, antibiotik, amoksisilin, tetrasiklin, daging ayam

Received 27 July 2018 | Revised 3 September 2018 | Accepted 26 November 2018

*Corresponding author at: Department of Chemistry Pharmacy, Sekolah Tinggi Ilmu Farmasi Riau, Pekanbaru

E-mail address: mustikafuri@gmail.com

Copyright (C) 2018 Published by Talenta Publisher, Print ISSN : 2615-6199, Online ISSN : 2620-3731

Journal Homepage: https://talenta.usu.ac.id/index.php/idjpcr 


\section{Introduction}

Livestock products are required in human diet as protein sources. Animal proteins become very important because contain amino acids which are required in human. However, livestock products is not always safe to consume but may have harmful effect in human health. Therefore, livestock products safety is the primary requirements [1].

Based on Bahri, et. al. (2000) most of the foodstuff factories of animal used antibiotics in their products [2]. The use of antibiotics especially for poultry use tends to be excessive and not complied with the regulation of the correct use of antibiotics [3]. The continuous use of antibiotics continuously (withdrawal time) in veterinary can leave some antibiotic residues in livestock products. It cause adverse effects on consumers' health such as allergic reactions, drug resistant and toxic effects [4].

The Inter-State School of Veterinary Science and Medicine (EISMV) reported that from 100 chicken's thigh and breast meats of $20 \%$ contained antibiotic residues with $15 \%$ in chicken's thigh meats and 5\% in chicken's breast meats [5]. According to Shankar, et. al. (2010), analysis of antibiotic residues divided into screening studies (qualitative studies) and confirmation studies (quantitative studies) [6].

Zhou (2010) and Fang (2007) have found that high performance liquid chromatography-mass spectrometry (HPLC-MS) was the best method to analyze the present and the level of antibiotic residues in chicken meat. This method is very sensitive, simple, faster and it's reliable method for analyze the chemical compounds in low concentration $[7 ; 8]$.

\section{Materials and Methods}

\subsection{Preparation of Samples}

This research used experimental method. The samples were obtained randomly from some of chicken slaughter houses in traditional market. The samples were wrapped in polyethylene bags and stored in freezer at temperature of $\pm 20^{\circ} \mathrm{C}$ before conducting the analysis/

\subsection{Preparation of HPLC-MS}

The system used XBD-C18 $(4.6 \times 30 \mathrm{~mm} \times 1.8 \mu \mathrm{l})$ column. The mobile phases consisting of $0.1 \%$ formic acid solution in water: $0.1 \%$ formic acid solution in methanol $(98: 2)$, was pumped at a flow rate of $0.5 \mathrm{ml} / \mathrm{min}$ and using mass spectrometry detector [7]. The condition of detector: quadropol temperature $\left(100^{\circ} \mathrm{C}\right)$, gas temperature $\left(350^{\circ} \mathrm{C}\right)$, drying gas $10 \mathrm{~L} / \mathrm{min}$, ionization using ESI mode with positive ionization pettern. Based on Zhou (2010), the pump using steady flow with gradient elution technique (Table 1). 
Table 1. Gradient Elution HPLC-MS

\begin{tabular}{cccc}
\hline $\begin{array}{c}\text { Gradient time } \\
(\mathbf{m i n})\end{array}$ & $\begin{array}{c}\text { Flow rate } \\
(\mathbf{m l} / \mathbf{m i n})\end{array}$ & $\begin{array}{c}\mathbf{0 , 1} \% \text { formic acid } \\
\text { solution in water }\end{array}$ & $\begin{array}{c}\mathbf{0 , 1} \% \text { formic acid solution } \\
\text { in methanol }\end{array}$ \\
\hline 0.0 & 0.5 & 98 & 2 \\
0.3 & 0.5 & 98 & 2 \\
7.27 & 0.5 & 20 & 80 \\
7.37 & 0.5 & 1 & 99 \\
8.27 & 0.5 & 1 & 99 \\
13 & 0.5 & 98 & 2 \\
\hline
\end{tabular}

\subsection{Recovery Prosedure}

Recovery test from modification of antibiotic residues method in chicken meat: amoxicillin and tetracycline standard solution with concentration of $0.2 \mathrm{ppm}$ was added into five grams of chicken meat (6x)m, homogenized then using vortex, centrifuged for $5 \mathrm{~min}$ at $5000 \mathrm{rpm}$ for 1 min. The supernatant was separated from the pellet and mixed then with the first supernatant. The supernatant was poured into measured flask of $25 \mathrm{ml}$ and filled with water solution and acetonitrile $(2: 8, \mathrm{v} / \mathrm{v})$ up to the mark line, filtered using PTFE of $0.2 \mu \mathrm{m}$ and detected by high performance liquid chromatography-mass spectrometry detector.

\subsection{Antibiotic Assays in Chicken Meat}

Analysis of antibiotic residues in 45 samples from traditional market in Medan used modification method above.

\section{Result and Discussion}

Chicken meats obtained from the 5 traditional markets amounted to 9 samples, so all of the samples were 45 .. This is related to that consumtion pattern which shows that chicken's thigh and wing were likely consumpt than breast [9].

Antibiotics levels of chicken meat was determined using Reverse Phases High Performance Liquid Chromatography equipped with mass spectorometry detector. Mass spectrometry used in the instrument was ESI (Electrospray Ionization). According to Cappiello, (2007), ESI is an ion generating technology by spraying analyte in the form of charged droplets obtained from the solvent used then the solvent will evaporate to produce ion charged samples [10].

Table 2. Ion Polarization Result by HPLC-MS

\begin{tabular}{cccc}
\hline Antibiotics & Fragmentation & Ion Molecule Mass & Ion charge/ Ion Precursor \\
\hline Amoxicillin & Positive & 365.1 & 366.1 \\
Tetracycline & Positive & 444.5 & 445.1 \\
\hline
\end{tabular}


The results obtained for the ionization of amoxicillin and tetracycline antibiotics was ions with positive ionization patterns with m / z 366.1 and m / z 455.2 as shown in Figure 1. The process of ionizing antibiotics formed by the solvent which were water and methanol with the addition of $0.1 \%$ formic acid helps to donate protons in the process, therefore molecules formed were the positive ionization amoxicillin and tetracycline $[\mathrm{M}+\mathrm{H}]+$ where $\mathrm{M}$ defined as parent molecule of a substance and $\mathrm{H}$ was hydrogen atom [11]. This caused the next analysis process to use the measurement of Selection Ion Monitoring (SIM) Method which is a compound measurement method that only detected a certain charged ion needed.
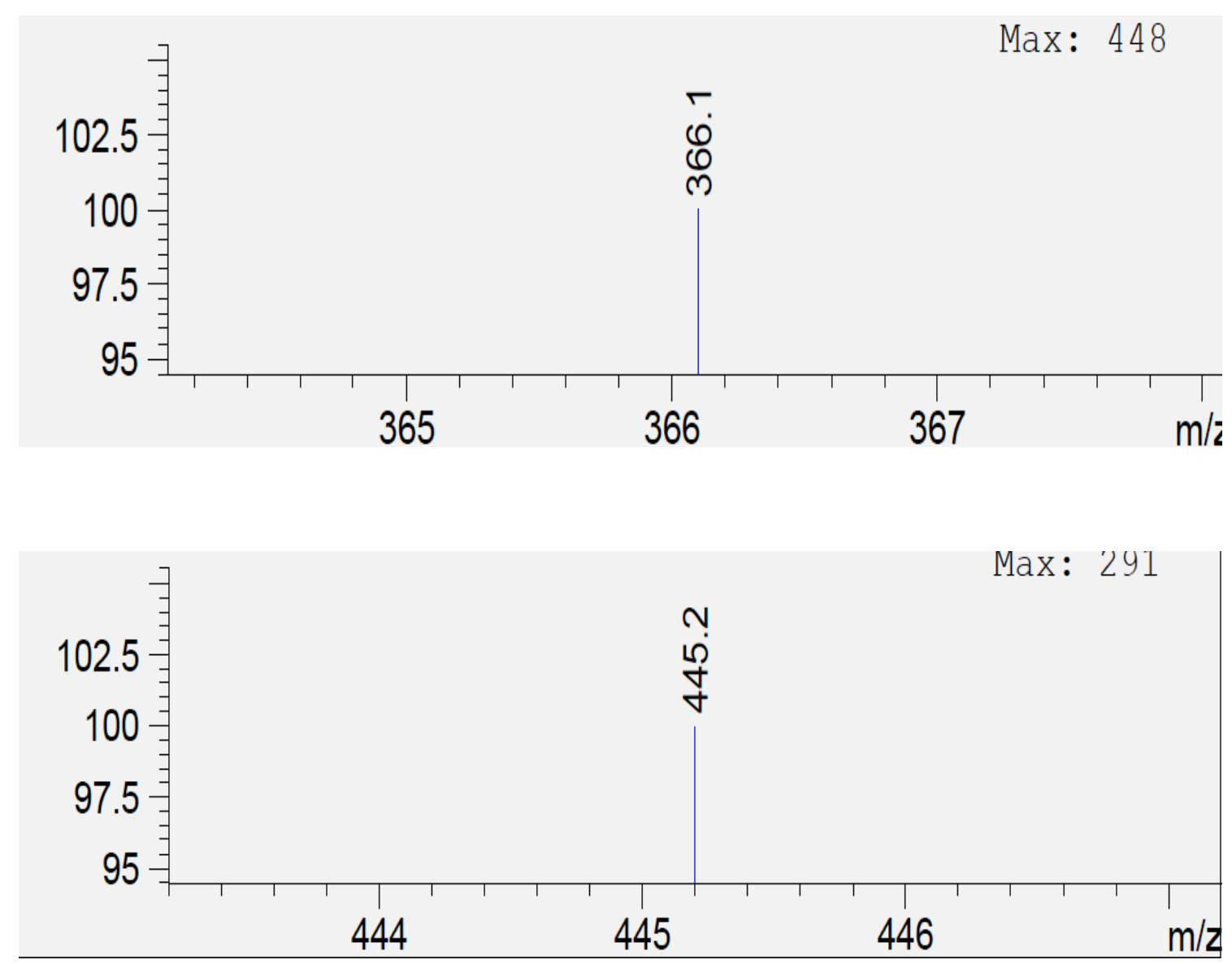

Figure 1. Positive Ionization pattern of Amoxicillin and Tetracycline

The recovery test result of the three trials which was added $100 \%$ of amoxicillin and tetracycline standard solution with concentration of $0.2 \mathrm{ppm}$, was shown in Table 3 
Table 3. Recovery Test Result of Chicken Meat Sample Which was Added Amoxicillin and Tetracycline Standard Solution with Concentration of $0.2 \mathrm{ppm}$

\begin{tabular}{ccccc}
\hline $\begin{array}{c}\text { Addition of Standard } \\
\text { Antibiotics }\end{array}$ & $\begin{array}{c}\text { Analysis Result } \\
(\boldsymbol{\mu g})\end{array}$ & $\begin{array}{c}\text { Recovery Result } \\
(\boldsymbol{\%})\end{array}$ & $\begin{array}{c}\text { Mean } \\
\text { Recovery } \\
\text { Value (\%) }\end{array}$ & RSD \\
\hline & 0.1765 & 88.25 & & \\
& 0.1958 & 97.90 & & \\
Amoxicillin 0.2000 (ug) & 0.2080 & 104 & 98.13 & 0.28827 \\
& 0.2020 & 101 & & \\
& 0.2007 & 100.35 & & \\
& 0.1956 & 97.3 & & \\
& 0.1692 & 84.6 & & \\
Tetracycline 0.2000 & 0.1653 & 82.65 & & \\
(ug) & 0.1664 & 83.2 & & \\
& 0.1545 & 77.25 & & \\
& 0.1634 & 81.7 & & \\
\end{tabular}

*RSD: Relative Standard Deviation

Based on the residue analysis of amoxicilllin and tetracycline in chicken meats result, from all sixth recovery test with addition of $100 \%$ with concentration of $0.2 \mathrm{ppm}$, meanrecovery value obtained from each test was $98.13 \%$ for amoxicillin and $81.17 \%$ for tetracycline. The mean recovery values were included in the good recovery range (80-120\%), therefore the method modification was good enough and suitable to analyze amoxicillin and tetracycline residues in chicken meat [12].

Modification of this method is quite effective in the use of chemicals in the extraction stage, which issufficient by the use of organic solvents and water. Compared to the purification method using catrigde, it will reduce the analysis time and has higher selectivity than the solvent extraction technique. Extraction using a solvent is not sufficient to reduce the influence of a disturbing sample matrix [13]. However, from the data of the research above, concluded that the analytical procedure in this research can be used for the determination of antibiotic content of amoxicillin, tetracycline, in chicken meat sample because it has fulfilled the validation requirement of the method with good precision because the relative standard deviation obtained has fulfilled the requirement which is smaller than 5\% [14].

Result of residue analysis method development modification of amoxicillin and tetracycline tried toward 45 samples that were taken from five traditional markets in Medan and the analysis result present on the Table 4. 
Table 4. Result of the Analysis of Amoxicillin and Tetracycline Residues in Chicken Meat

\begin{tabular}{ccc}
\hline \multirow{2}{*}{ Sample Code } & \multicolumn{2}{c}{ Range of Antibiotics Level $(\boldsymbol{\mu g} / \mathbf{g})$} \\
\cline { 2 - 3 } & Amoxicillin & Tetracycline \\
\hline PS & Negative & $0.6300-0.6963$ \\
PP & Negative & Negative \\
PA & Negative & Negative \\
PSL & Negative & Negative \\
PB & Negative & $0.1157-1.4436$ \\
\hline
\end{tabular}

Based on the analysis of amoxicillin and tetracycline residues towards 45 samples from five traditional markets showed that eighteen samples of chicken meats from two traditional markets in Medan are positively contain tetracycline residue while no amoxicillin residue was detected in the entire chicken samples. From all the positive samples, found that the residue level of tetracycline in chicken meats are in range of $0.1157-1.4436 \mu \mathrm{g} / \mathrm{g}$, which exceed the maximum level for tetracyclin residue allowed in foodstuffs of animal origin which is $0.1 \mathrm{ug} / \mathrm{g}$, this was exceeding the requirements of SNI No. 01-6366-2000 [15].

\section{Conclusion}

The determination of antibiotic residues in chicken meat that were collected from five markets in Medan apparently contained antibiotic residues tetracycline. The level of tetracyclin residue in chicken meat was $0.1157-1.4436 \mu \mathrm{g} / \mathrm{g}$, which exceed the maximum level for tetracyclin residue allowed in foodstuffs of animal origin which is $0.1 \mathrm{ug} / \mathrm{g}$, this was exceeding the requirements of SNI No. 01-6366-2000.

\section{REFERENCES}

[1] F.G. Winarno, Food Law, Collection of Papers at the 2nd Deliberation and Scientific Seminar of the Indonesian Health Laboratory Technological Association, Jakarta, 1996.

[2] S. Bahri, T.B. Kusumaningsih, A. Murdiati, (Analysis of Animal-based Food Policy (especially laying and broiler chickens), Research Report, Center for Animal Husbandry Research and Development, Bogor, 2000.

[3] M.E. Doyle, "Veterinary drug Residues in Processed Meats-Potential Health Risk", Reviews of the scientific Literatur. Food Research Institute. 2006

[4] T. Yuningsih, B. Murdiati, and S. Juariah, "The Existence of Tilosin (Makrolide Group) Antibiotic Residues in Chicken Meat from Sukabumi, Bogor and Tangerang". In Proceeding of Seminar Nasional Teknologi Peternakan dan Veteriner. 2005

[5] R.B. Alambedji, A.J. Akakpo,A. Teko-Agbo, B. Chataigner, A. Steven, and B.Garin, "Control of Residues: Example of Antimicrobials in Food in Senegal" In Proceeding of OIE Conference on Veterinary Medicinal Product, pp. 25-27. 2008

[6] S. Shankar, B. BP, M. Prabhu, B. BH, C. Chandan, S. S, R. Ranjith, D. Shivakumar, and V. V, "Rapid Methods for detection of Veterinary Drug residues in Meat," Veterinary World, p. 241, 2010.

[7] Y. Zhou, D. Lavorato, and M. Terrell, "Rapid LC/MS/MS Analysis of Antibiotics in Meat for Human Consumption", Application Note Agilent Technologies, pp. 1-4. 2001. 
[8] Y. Fang, J. Zweigenbaum, and Z. Wang, "Detection, Confirmation, and Quantification of Chloramphenicol in Honey, Shrimp and Chicken Using the Agilent 6410 LC/MS Triple Quadrupole" Application Note. Agilent Technologies Inc. 2007.

[9] P. Simatupang, and J. Hestina, "Policy Support in Livestock Agribusiness Development Enters Free Trade. National Seminar and Expose. Animal Crop Integration System, Center for Animal Husbandry Research and Development" Denpasar, pp. 402, 2004.

[10] A. Cappiello and P. Palma, "Preface," Comprehensive Analytical Chemistry, pp. xvii$\mathrm{x}$ viii, 2018.

[11] C.M. Tang, Q.X. Huang, Y.Y. Yu, and X.-Z. Peng, "Multiresidue Determination of Sulfonamides, Macrolides, Trimethoprim, and Chloramphenicol in Sewage Sludge and Sediment Using Ultrasonic Extraction Coupled with Solid Phase Extraction and Liquid Chromatography-Tandem Mass Spectrometry," Chinese Journal of Analytical Chemistry, vol. 37, no. 8, pp. 1119-1124, Aug. 2009.

[12] J. Ermer and J. H. McB. Miller, Eds., "Method Validation in Pharmaceutical Analysis," Jan. 2005.

[13] D. Suryani, "Validation of the Tetracycline Antibiotic Residue Analysis Method in Broiler Chicken by High Performance Liquid Chromatography", Essay, Faculty of Math and Science, Bogor Agricultural Institute, Bogor, p. 20. 2005

[14] A. Rohman, Chemical Pharmaceutical Analysis, First print, Student Library, Yogyakarta, pp. $465-469.2007$

[15] National Standardization Agency, "SNI 01-6366-2000. Maximum limit of microbial contamination and maximum residual limit in animal origin food ingredients" National Standardization Agency. Jakarta. 